\title{
Blurring Northeast Mexican Societies: An Approach to Cultural Capital and Results of the PISA Test
}

\author{
Mónica Mendirichaga Pérez-Maldonado ${ }^{1}$, Alberto Ochoa-Zezzatti ${ }^{1}$, \\ Aida Yarira Reyes Escalante ${ }^{1}$, Roberto Mendirichaga-Dalzell ${ }^{2}$, Sandra Bustillos ${ }^{1}$ \\ ${ }^{1}$ Universidad Autónoma de Ciudad Juárez (UACJ), Mexico \\ ${ }^{2}$ Universidad de Monterrey (UDEM), Mexico
}

\begin{abstract}
The present research shows, from the results of the PISA Test of the years 2012-2015, the difference that exists in the societies of the northeast, comparing the state of Nuevo León with the states of Coahuila, San Luis Potosí and Tamaulipas. It seeks to evaluate the field of reading in each of these regions, coupled with the results of mathematics and science. Taking from the PISA Test 38,251 records, those of these four states are included, giving a total of 4,764 records. For the above, it is basic what is related to the reading process and the existence of libraries, as well as other exogenous variables, all this done through the software of the Weka 3.9.2 program.
\end{abstract}

Keywords: cultural capital, PISA test, northeastern Mexico, incentive of reading, use of libraries.

\section{Introduction}

Understanding adequately the representation of knowledge in a group of societies where children of 15 years old need to have a job, is basic to establish educational policies associated with this group of consolidated economies that make up the OECD (Organization for Economic Cooperation and Development). When we talk about knowledge, it refers to the most important aspect or component of the current civilization, because it is more than natural resources, money and other goods. Nowadays, whoever possesses the knowledge has the key of power, hence this key factor for the future of Mexico and the world is included. The PISA test evaluates not only the 43 countries that make up the OECD, but also political entities from other countries, such as: Macao, Wales or even the Basque Country; that is to say, that the developed countries can not disassociate themselves from the underdeveloped ones. In fact, today new economic-political alliances have been formed that no longer obey the traditional definitions of groups and alliances.

Data Mining allows you to identify hidden patterns in large groups of information. It is a new technology, which makes a great contribution to the social and economicadministrative sciences. There are several studies conducted using data mining such as the study of: Data Mining Applied for the Identification of Risk Factors in Students [1], Evaluation of CENEVAL Admission Surveyed Parameters for Students that are Candidates to Enter the Higher Education, ITP Study Case [2], Modeling Students' Dropout in Mexican Universities [3]. 
Through the Weka program 3.9.2. the data about the PISA Test are analyzed and compared to arrive at specific conclusions. The methodology that is carried out in the present research is applied to the analysis of the results of the PISA Test of the years 2012-2015 in the northeast societies, comparing the state of Nuevo León with the states of Coahuila, San Luis Potosí and Tamaulipas. The Pygmalion effect consists in the change of behavior of a group that shares similar induced characteristics, by an expectation of one of them; this phenomenon has been documented since the sixties, but it appears here with some details of the investigation based on accurate information, because it is by means of the information obtained in the evaluation of the PISA Test that it is possible to arrive at the required information. [4].

\section{The Northeast Mexican}

It is known as the Mexican northeast societies (mns), the integration of the states of San Luis Potosí, Coahuila, Tamaulipas and Nuevo León. Before the Treaty of GuadalupeHidalgo in 1848, Texas was part of this subregion and, although politically it is no longer part of the American Union, in some way it is from the cultural point of view part of Mexico. San Luis Potosí is the most consolidated entity geographically, culturally and politically. It had a great miscegenation.

During the viceroyalty, it played an important role in advancing the New Spain model to the north, through evangelization, military development, economy and education. Presents several areas, such as: The Altiplano, the Middle region and the Huasteca. In the Altiplano region, a large part of it's history "seems to be linked to the discovery and exploitation of subsurface resources", while the Huasteca and a good part of the Middle region are mainly agricultural regions. At "El Ébano" the first oil well of Mexico was located. Much of the problem of emigration to more distant population centers or even abroad, is due to the hoarding of the means of production and the use and possession of the land, in addition to the problem of water and desertification [5]. From San Luis Potosí and Zacatecas, culture passed to Nueva Extremadura or Coahuila. Five subregions are located here: Saltillo, Monclova, Parras-La Laguna, the Carboniferous Region and Guerrero, each with it's particular vocation and uniqueness. Its demographic growth was slow and gradual. It's culture can not be understood without the Tlaxcalan presence. "As part of the modernization of the Coahuila society, since the second half of the 19th century education was one of the aspects that were most encouraged" [6].

It should not be forgotten that there existed at the end of this century and at the beginning of the 20th century a fundamental economic axis that came from Chihuahua, passed through Durango, reached La Laguna, then followed Saltillo, and continued in Monterrey, to finish in Laredo. Tamaulipas, long territory that goes from the border with the United States to Veracruz, was founded in 1700 by José de Escandón and the first settlers, who came mostly from the New Kingdom of León. Its native population were: olives, reeds, janambres and huastecos. Until the Independence, the Nueva Santander or Tamaulipas depended militarily and economically on the intendency of San Luis Potosí. The Franciscan missions contributed to the pacification. From the 19th century, the main population centers were: Aguayo (later Ciudad Victoria), El Mante, 
Tampico, Tula, Camargo, Matamoros and Reynosa. Filibusterism, rustling and concentration of capital hindered integration. Foreign investment in the field and oil explotation were factors that disrupted traditional sources of wealth. Then came the Revolution, which was factional fighting. In education and culture, Tamaulipas saw it's awakening with the Obregonist reconstruction and the program of José Vasconcelos in SEP. "With the support of Portes Gil, President Cárdenas began the stage of institutional incorporation [...]".

They excelled in secondary high education, the San Juan Institute, in Matamoros, and the Scientific and Literary Institute, in Ciudad Victoria. The demographic dispersion and the ruggedness of the Sierra Madre made literacy difficult. At the end of the 20th century, the maquila industry strongly influenced the economic takeoff of Tamaulipas, which in some way stopped emigration (ibid p.62). Finally, the old New Kingdom of León, then Nuevo León after Independence, is the fourth entity that integrates this northeast. It had a primary economy based on agriculture, livestock and trade, which was modified by the industrialization of the mid-twentieth century, the result of the Reyista era and postrevolutionary governments. Formal education was present with institutions such as the College-Seminar, the State Civil College, the Escuela Normal para Profesores and, already in the twentieth century, with the University of Nuevo León (UNL, in Spanish, and now UANL), the Tecnológico of Monterrey (ITESM, in spanish) and other universities.

The particularity of this entity is that it concentrates most of its population in the capital city, not registering other notable poles of development. It turns out to be the most important entity in the north, basing most of its economy on services. It maintains an organic education system that is close to that of its neighbor Texas and other European and Asian countries [7].

\section{Cultural Capital: Reproduction and PISA Test}

By cultural capital is usually understood the intangible that occurs through generations in a particular country society; the result of many years of work, study, savings and effort. In the case of México, this cultural capital is integrated with the rich Prehispanic Past; the three centuries of the Viceroyalty; what is produced in Independence; the addition in the Reforma and the Porfiriato; what was generated in the Revolution and Reconstruction, plus the whole maturity process of the 20th century, to enter a 21 th century full of challenges, but also of opportunities. Annette Lareau and Jessica McCrory, in the chapter entitled "Class, cultural capital and institutions: the case of families and schools", warn that in the United States, "Americans are convinced that by the power of individualism and only through it they forge the opportunities and the options reached".

The authors conclude that, in the case of the United States, the most part that comes from the cultural capital is that "a better education is a universally accepted value, in relation to parents and the education of their children [8]. According to the aforementioned authors, one should consider the approach of Pierre Bourdieu, who "uses the concept of cultural capital to explore not only how the basic social class produces individuals with different interactional resources, but how these resources can be used to produce different social benefits [9]." Bourdieau's approach, carried out together with 
Claude Passeron at the beginning of the fifties of the last century, with something that they called reproduction, derived from Marxist theory in it's concept of surplus value and appropiation, has been worked by many authors and applied to education, reading, art, culture, and other aspects of social life. Sandrine García and Franck Poupeau, in the chapter: "The measurement of 'school democratization'. Notes on the sociological uses of statistical indicators", which is part of the book Pierre Boudieau. Symbolic capital and social magic, by Isabel Jiménez, coordinator, possess a series of elements that have to do tangentially with our work on reading process, school, the PISA test and community libraries.

For García and Poupeau, the statistical indicators of school democratization require epistemological surveillance. Taking about the case of four French business schools, "the great prestigious schools have opened very little to the popular classes", but from the above can not easily conclude a direct relationship between social class and professional success. We should also consider what is related to the pedagogical teams and the effectiveness of the school or establishment, as indicated by the aforementioned authors [10]. It is necessary to see the result of the PISA test in México during the last years, and specifically in the northeast; to try to establish if there is any direct relationship between reading and academic success: between the effectiveness of reading done in community libraries and school success; between social class and professional success; between the parents' economic income and the children's school results, which may be far from the objective of this paper.

\section{$4 \quad$ Incentive of Reading Process and Using Libraries}

It can be read in many different ways: in a traditional way, in the printed book, in the newspaper, in the magazine, in the comic; and now, also on the ipad, the internet, the cell phone or the kindle. What percentage of Mexicans do it in one way or another is something that has yet to be clarified, since the research work on it does not define it completely. But if we ask to the current university students what percentage of what they read do it in a conventional or traditional way, it will hardly exceed 20 points what is read in print. Juan Domingo Argüelles considers that "[...] they read books on the screen who also read them on paper, and others do not read them on any medium" [11]. What should be a desideratum is that our children, youth, adults and the elderly read the best of universal literature, in the fields of science, arts and humanities. So, if this seems to be the reality, where the most powerful sources of information are television and social networks, why return to the subject of libraries and, specifically, community libraries? Because we consider that these represent a very good option for the intellectual, ethical and aesthetic elevation of large masses of unemployed, workers, housewives, students and children who find it very difficult to acquire books or enter to the traditional internet or its databases, which have become unreachable in their price or difficult to locate.

In her Master's Thesis about libraries, Mónica Mendirichaga Pérez-Maldonado says that it would be desirable for there to have an active participation from government and civil society. Also, in terms of facilities, that they adequate; that there was an open and ready staff to meet the needs of users, texts that would invite reading and specialized materials; likewise, computers that had access to the information superhighway [12], 
as benefits the vision of what Juan José Arreola, once referred to as schools, would describe as "true centers of exciting experiences"[13]. That is to say, the library must be a cultural and artistic center, where the librarian becomes its main promoter, given that these libraries are located in rural areas or in depressed urban areas. According to what we have been able to analyze in this work, the PISA test has a direct relationship with the cultural capital of the region, with the socioeconomic and cultural level of the parents of these children, and with the possibilities of economic and social advancement. Graduates of technical schools and university centers in the country, which brings us to the next point of this research.

\section{$5 \quad$ PISA Test (Program for International Student Assessment)}

The Human Development Index (HDI) is an indicator of the achievements obtained in the fundamental dimensions of human development, which are: a long and healthy life, acquiring knowledge and living a dignified life. They are the indices of each of the three dimensions. It can be said that the HDI of human development is very high in Nuevo León, followed by Coahuila, Tamaulipas is high in human development and in the middle human development is San Luis Potosí. (See Table 1.)

Table 1. Own elaboration. Inspired by the HDI Table (Human Development Index) of the states of Nuevo León, Coahuila, Tamaulipas and San Luis Potosí [14].

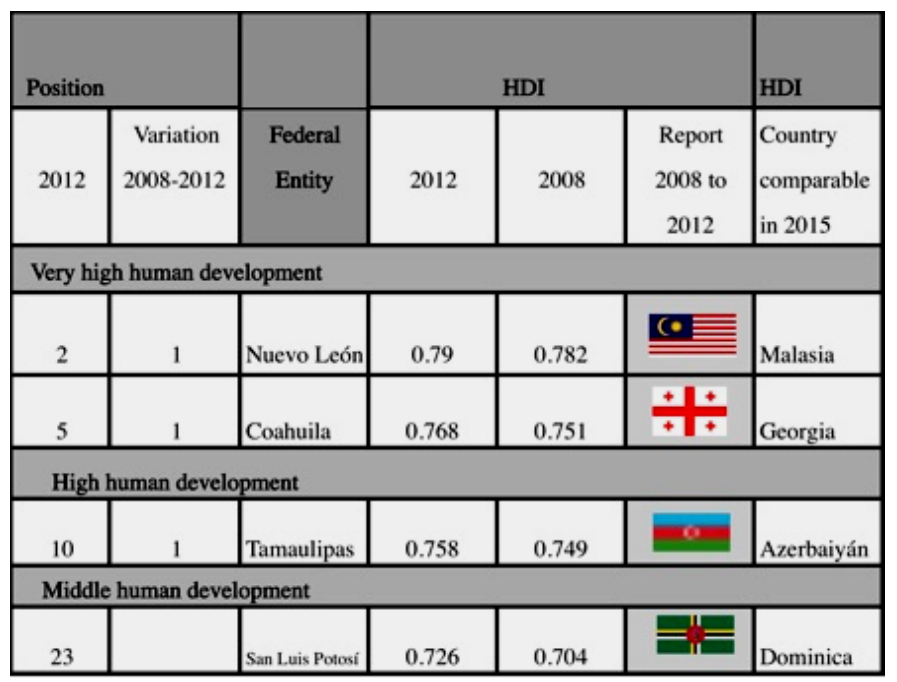

In the results of the 2012 PISA educational evaluation (in points), Mexico in the area of reading has 424 (No. 52), then in science 415 (No. 55) and finally in mathematics 413 (No. 53). In the first three places in the world in reading is Shanghai, China 570 (No. 1), Hong Kong 545 (No. 2) and Singapore 542 (No. 3). In science is Shanghai, China 580 (No. 1), Hong Kong, China 555 (No. 2), Singapore 551 (No. 3). In mathematics there are Shanghai, China 613 (No. 1), Singapore 573 (No. 2) and Hong Kong, China 561 (No. 3). [15]. (See Table 2.) 
Average trend of performance in science since 2006: Mexico is at zero, while the United Arab Emirates are those who are located in the highest place.

Table 2. Average performance trend in science since 2006. [16]

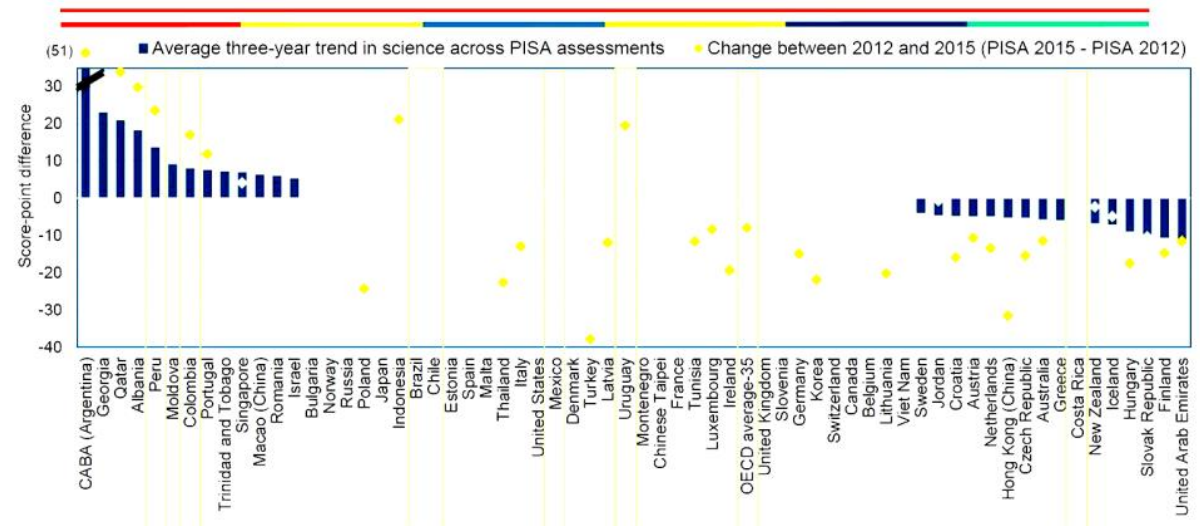

\subsection{Questions of Great Relevance in the PISA Test}

Within the International Program for the Evaluation of the OECD Student (Organization for Economic Cooperation and Development) PISA 2009, the Student Questionnaire includes those considered most important. The sections chosen for this topic are those related to: family environment, your reading activities, the time dedicated to learning, school environment time, your Spanish classes, Libraries, your reading strategies and text comprehension and your educational career.

Section 2: Your family environment. It's about your family and your house. Some of the questions refer to the father, the mother, or the people who act as equivalents; for example, sponsors, uncles, brothers, stepparents, adoptive parents, in anothers Question 11. Does your mother have any of the following certificates?

Answer: (a) PhD; (b) bachelor's degree; university degree; technological degree; specialization or expertise; (c) superior technician.

Section 3: Your reading activities. Reading activities outside of your school Question 23. How much time do you spend reading for pleasure?

Answer: I do not read for entertainment; 30 minutes or less a day; More than 30 minutes, but less than 60 minutes a day; From 1 to 2 hours a day; More than 2 hours a day.

Section 4: Time dedicated to learn

Question 31. What type of classes do you currently attend outside of school hours? (This question refers only to the classes of the subjects you study at school and those you attend outside of school hours). Selecting: yes or no. 
Answer: (a) High performance classes in Spanish (Reading and Writing Workshop, Language and Literature); (b) High performance classes in Mathematics; (c) High performance classes in Science (Biology, Physics, Chemistry or Earth Sciences); (d) High performance classes in other subjects; (e) Regularization classes in Spanish (Reading and Writing Workshop, Language and Literature); (f) Regularization classes in Mathematics; (g) Regularization classes in Sciences (Biology, Physics, Chemistry or Earth Sciences); (h) Regularization classes in other subjects; (i) Classes to improve your ability to study.

Section 5: School environment time

Question 34. How much do you agree or disagree with each of the following statements about teachers in your school? (Mark only one option of each row). Selecting: totally agree, agree, disagree and totally disagree.

Answer: (a) I get on well with most teachers; (b) Most teachers are interested in my well-being; (c) Most of my professors really listen to what I have to say; (d) If I need extra help, I receive it from my teachers; (e) Most of my teachers treat me fairly.

Section 6: Your Spanish classes

Question 37. In your Spanish classes, (Reading and Writing Workshop, Language and Literature, etc.) how often does the teacher do the following things? (Mark only one option in each row). Selected: in all classes; in most classes; in some classes; never or almost never.

Answer: (a) The teacher asks his students to explain the meaning of a text; (b) The teacher's questions stimulate students to gain a better understanding of what they read; (e) The teacher encourages students to express their opinion about a text; (f) The teacher helps the students relate the stories they read with their lives; $(\mathrm{g})$ The teacher shows that the information in the texts is constructed from what the students know.

Section 7: Libraries

(In this section we will ask about the libraries, it could be the school library or those outside of your school). Selecting: several times a week; sometimes in the month; approx. once a month; sometimes a month and never.

Question 39. For the following activities, how often do you visit the library at your school?

Answer: (a) Ask borrowed books to read for pleasure; (b) Request borrowed books to do school work; (c) Work on assignments, course assignments or research papers; (d) Read magazines or newspapers; (e) Read books for pleasure; (f) Learning things that are not related to the course, such as: sports, hobbies, people or music; (g) Use the internet.

Section 8: Your reading strategies and text comprehension

Question 42. Purpose of the reading: You have just read a two-page long and a little difficult text about fluctuations in the water level of a lake in Africa. You have to write a summary. (How do you rate the usefulness of the following strategies for writing a summary of this two-page text?). Selecting from: (6) very useful to (1) for nothing useful. 
Answer: (a) I write a summary. Then I make sure that each paragraph is covered in the summary, because the content of each paragraph must be included; (b) I try to copy exactly as many sentences as possible; (c) Before writing the summary, I read the text as many times as possible; (d) I check carefully that the most important data of the text are included in the summary; (e) I read the entire text, underlining the most important sentences. Then I write them in my own words in summary form.

Section 9: Your educational career. (In this section you will be asked about the different aspects related to your school experience)

Question 47. Which of the following educational levels do you expect to finish? (Mark all that apply to your case).

Answer: (a) Junior High (escuela secundaria, in spanish); (b) Technical Professional; (c) High School (Bachillerato in spanish), ColBach (Bachelors), Vocational (Technical Education, post-secondary, Polytechnic Institute), Conalep (Technical Studies), etc.); (d) Higher University Technician; (e) Bachelor, Master Degree or Doctorate (PhD Degree).

\section{$6 \quad$ PISA Test (Program for International Student Assessment)}

\section{Test 1}

X: FAMSTRUC (Family structure)

Y: PROMREAD (Reading Average)

-Entity (Coahuila, Tamaulipas, Nuevo León and San Luis Potosí)

According to the analysis carried out, it has been possible to know the importance of the student having a nuclear family, since it will make better use of reading and this will be reflected in the average; secondly, we have the children who are cared for either by their mother or by their father; and finally there are students who are part of a mixed family. As for the results on the use of reading, we have first Nuevo León, then Coahuila, followed by Tamaulipas and, finally, San Luis Potosí.

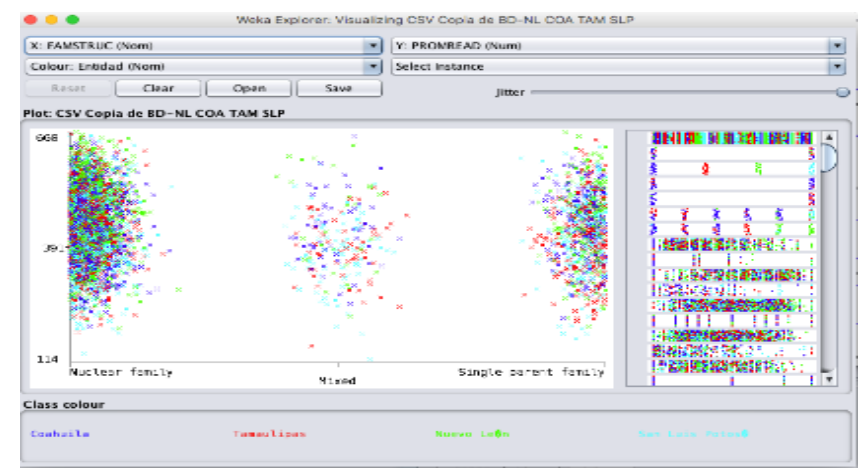

Test 2

X: Modality (Technical Secondary, General Baccalaureate, Technical Professional, Technological Baccalaureate, General Secondary and Telesecundaria (Distance Education). 
Y: ST30Q06 (Learn things that are not related to the course such as sports, hobbies, people or music). Question No. 39.

-ST39Q05 (Read books for pleasure). Question No. 30.

In the Baccalaureate level it has been possible to perceive that it is there where the student acquires greater knowledge and skills that are not necessarily related to the course. Such is the case of independent reading of school texts; the practice of a sport, playing a musical instrument, being part of a theater or dance group; to practice a hobby: to go to the cinema, to the theater, to concerts or dance shows, among a host of other possibilities.

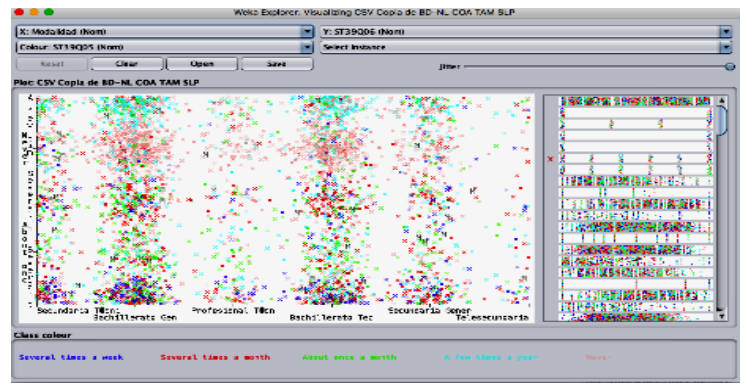

\section{Test 3}

X: ST20Q14 (Among the following levels of study, what is the highest level of education your father arrived at?). Question No. 14.

And: Entity (Coahuila, Tamaulipas, Nuevo León and San Luis Potosí).

-Gender (Female and Male).

Following the review of the results of the PISA test in relation to this issue, it has been found that there is a direct influence between the following two variables: if the male child has a father who studied, whether primary, secondary, high school, career, master or doctorate, this will lead to the likelihood that your child will aspire to study to the same level as his father did. Regarding the above, it is known that "the example drags" and that the child will have greater motivation if he expects to become equal or better than his parent. For this reason, a higher level of studies of the father, greater literacy skills will develop in the child, who in turn will impact on a high vocabulary, a higher capacity for synthesis and greater ease to perform processes related to the reflection and problem solving.

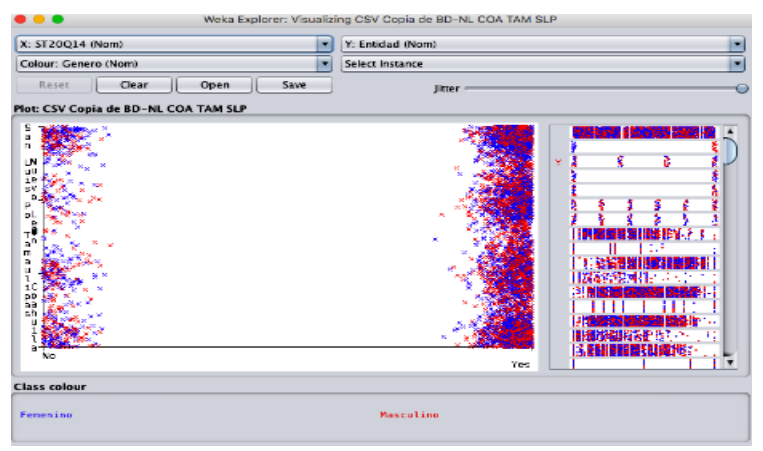




\section{How Things Happen and How Can They Be Improved?}

A public policy that specifies substantial changes in the educational paradigm of children and young people in the region should be channeled to increase the use of reading as part of the curriculum and also as an instrument for expanding knowledge and reinforcing attitudes and habits. Therefore, it can already be inferred, even if it is preliminary, that there are obstacles and barriers to overcome in terms of reading and writing, science learning, arts and deepening in humanities. Some will say that this occurs as a current phenomenon in all societies, from all continents and without differentiating the social stratum. But this does not deal with the root of the problem, nor does it contribute much to elucidating where we are standing.

Everything lies in a poor appreciation of the value of reading and how a great change in people can be achieved, in order to effect this transformation at the society level. It is thought that reading is unique to the humanities area and away from the sciences. That is why the ideal is that you can include reading and writing within all levels of study. What has been found so far is that the PISA test has obtained different scores in the four entities of the northeast of Mexico, together with other exogenous factors such as libraries, the mass media and social networks.

Finally, we propose a Model based on Structural Equations as is shown in Figure 1.

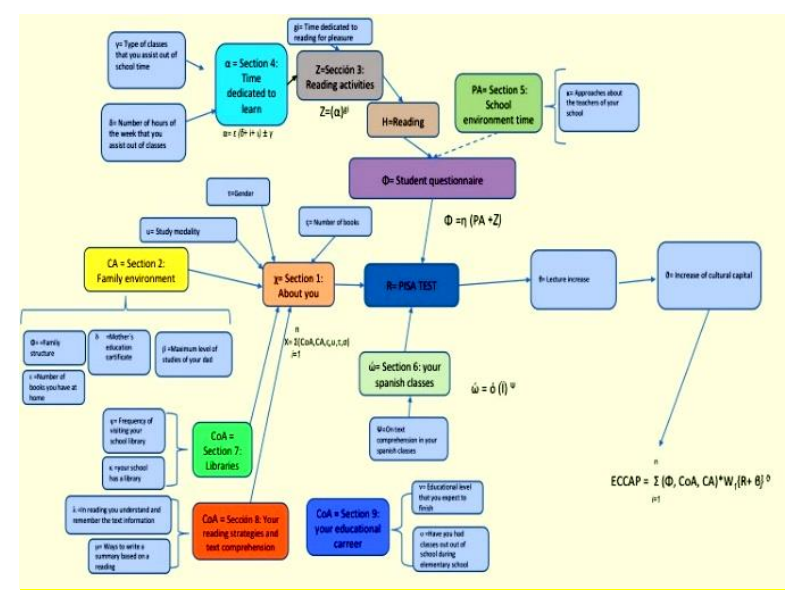

Fig. 1. Model associated with our research. (Source own).

\section{Conclusions}

A relevant aspect of this research is the use of Social Data Mining, in order to describe the best possible way to educational edges of the Northeast Mexican region and how this can determine the possibility of finding significant changes in future generations, this represented by means of software Weka 3.9.2., by means of the analysis of the results of the PISA test of the years 2012-2015 in the societies of the northeast, comparing the state of Nuevo León, with the states of Coahuila, San Luis Potosí and Tamaulipas. It is considered that reading, especially at early age, will be of great benefit 
so that in the future a 15-year-old adolescent, such as the one we are analyzing in this paper, will result in a better ability to write and read texts that are aligned to personal interests, or to the search for the truth. But what more do we aspire to find in a text, more than answers, ideas, new ways of seeing the world? We have to put all our effort into achieving an approach to reading, which forms more aware citizens interested in what has happened to us as a country and of what we want to project for the future, given that we have a strong cultural capital. That is why, taking advantage of the results of the PISA test will allow us not to make the same mistakes in educational fields but, rather, correct the way; take the helm again to build a society that, although it has much more access to information than previous generations, does not know how to find the truth. It is there where the libraries are the key piece.

We are inundated by fake news; for information that does not have reliable sources, by hundreds of leaders who want to move public opinion one way or the other. We need children and young people awake to learning, to the construction of knowledge and sensitive to the big world problems: inequality, extreme poverty, care of ecology and, above all, we need to believe in the value of communication face to face. Those of us who have had the great opportunity of having had an early childhood, where the evening was accompanied by a good story, a fascinating fairytale, an inspiring tale, we are, or should be, committed to the regeneration of a society that cries for the basics. That is why this research can gain relevance, not only from the sociological aspect, but above all through data mining (social data mining).

We rely on this transversality of knowledge to integrate the exact sciences, statistics, with something as essential as knowing where are we failing to get away from countries such as Shanghai, China, which has the first place in the world in reading. There is much to be done, but we hope that this research brings us closer and closer to achieving the results we deserve as a country. Mexico is a rich country in culture, traditions and values, and reading is the opportunity to break paradigms or judgments that do not allow us to grow as a society.

\section{References}

1. Reyes-Nava, A., Flores-Fuentes, A., Alejo, R., Rendón-Lara, E.: Minería de datos aplicada para la identificación de factores de riesgo en alumnos. Research Computer Science 139, pp. 177-189 (2017)

2. Rodríguez-Maya, N. E., Lara-Álvarez, C., May-Tzuc, O., Suárez-Carranza, B. A.: Modeling Students' Dropout in Mexican Universities. Research in Computing Science 139, pp. 163-175 (2017)

3. Gonzalez-Marron, D., Enciso-Gonzalez, A., Hernandez-Gonzalez, A.K., Gutierrez-Franco, D., Guizar-Barrera, B., Marquez-Callejas, A.: Evaluación de parámetros de encuesta de ingreso del CENEVAL para alumnos candidatos a ingresar al nivel superior, caso de estudio ITP. Research in Computing Science 139, pp. 135-147 (2017)

4. Ochoa, A., Tcherassi, A., Shingareva, I., Padméterakiris, A., Gyllenhaale, J., Hernández, J., Italianitá, A.: Discovering a Pygmalion effect on Italian communities using data mining. Advances in Computer Science and Engineering 57 (2006)

5. Monroy. M.I., Calvillo, T.: Breve historia de San Luis Potosí. Colmex-FCE, Ciudad de México, pp. 16 y 36-39 (1997)

6. Santoscoy, M.A., Gutiérrez, L., Rodríguez, M., Cepeda, F.: Breve historia de Coahuila. Colmex-FCE, Ciudad de México, p. 313 (2000) 
7. Herrera, O.: Breve historia de Tamaulipas. Colmex-FCE, Ciudad de México, pp. 83, 161 $163,208-212$ y 284 (1999)

8. Cavazos-Garza, I.: Breve historia de Nuevo León. Primera edición, Colmex-FCE, Ciudad de México, pp. 113, 156, 168-173-176, 200 y 204-213 (1994)

9. Lareau, A., McCrory, J.: Class, cultural capital, and institutiones: the case of families and schools, capítulo cuarto en Facing social class. En: Fiske, S.T., Markus, H.R. (editors). Rusell Sage Foundation, New York, pp. 61-86, (2012)

10. García, S., Poupeau, F.: La medición de la democratización escolar. Notas sobre los usos sociológicos de los indicadores estadísticos. En: Bourdieu, P.: Capitalismo simbólico y magia social. Segunda edición. Siglo XXI Editores, Ciudad de México, pp. 205-235 (2014)

11. Argüelles, J.D.: Por una universidad lectora. Laberinto-UJAT, p. 61 (2015)

12. Pérez-Maldonado, M.M.: Análisis de las bibliotecas comunitarias del estado de Nuevo León. Tesis de la Maestría en Gestión de Servicios Informativos de la UACJ. DOI: 10.13140/RG.2.2.33746.04801 [recuperado en junio 2018]

13. Roberto, M.: Tres breves lecciones de literatura, por Juan José Arreola. En Armas y Letras Núm. 35, marzo-abril, pp. 49-50 (2002)

14. Elaboración propia. Inspirada en la Tabla IDH (Índice de Desarrollo Humano) de los estados de Nuevo León, Coahuila, Tamaulipas y San Luis Potosí. Anexo: Entidades federativas de México por IDH. [Recuperado de: https://es.wikipedia.org/wiki/Anexo:Entidades_federativas_de_M\%C3\%A9xico_por_IDH]

15. Vargas, A.M.: Resultados del examen de evaluación educativa PISA 2012 (en puntos). Matemáticas, Lectura y Ciencias (2012) [Recuperado de: https://www.google.com/search?q=resultados+pisa\&source $=1 \mathrm{nms} \& \mathrm{tbm}=\mathrm{isch} \& \mathrm{sa}=\mathrm{X} \& \mathrm{ved}=0 \mathrm{ahUKEwim} 86$ uSodHcAhUDUK0KHcNYC1wQ_AUICigB\&biw=1354\&bih=671\#imgrc =odQHg7m sqhG06M]

16. Tendencia promedio de Prueba PISA sobre el desempeño en ciencia desde 2006. [Recuperado de: https://www.google.com/search?biw=1354 \&bih=671\&tbm=isch\&sa=1\& ei $=\mathrm{kHBkW}-2 \mathrm{OA} 8 \mathrm{~S} 8 \mathrm{sQX}$ qnL6ICg\&q=tendencia+promedio+de+desempe $\% \mathrm{C} 3 \% \mathrm{~B} 1 \mathrm{o}$ + pisa+2006\&oq=tendencia+promedio+de+desempe $\% \mathrm{C} 3 \% \mathrm{~B} 1 \mathrm{o}+$ pisa+2006 \&gs_l=img.3...18183.23325.0.23946.25.23.0.0.0.0.173.2316.14j8.22.0...0...1c.1.64.img.. 11.9.850...35i39k1.0.a921JaD2Bss\#imgrc $=\mathrm{vxOwJmR9m67 \times 5M]}$ 